\title{
THE ROLE OF HYPOXIA-INDUCIBLE FACTORS IN THE DEVELOPMENT OF CHRONIC PATHOLOGY
}

\author{
N. S. SHEVCHENKO, N. V. KRUTENKO $\bowtie$, T. V. ZIMNYTSKA, K. V. VOLOSHYN \\ V. N. Karazin Kharkiv National University, Department of Pediatrics No. 2, Ukraine; \\ 凶e-mail:n.v.krutenko@karazin.ua
}

Received: 13 October 2020; Accepted: 07 July 2021

This review highlights the current understanding of hypoxia-inducible factors (HIFs) role as regulators of oxygen-dependent reactions and inducers of genes expression in human organism. The focus is on the most significant relationships between the activation or inhibition of the HIFs intracellular system and development of the inflammatory process in various organs, chronic diseases of gastrointestinal tract, osteoarticular system, kidneys as well as hematological, endocrine and metabolic disorders.

Ke y wo rd s: HIFs, hypoxia, metabolism, chronic pathology, pathogenesis.

$\mathrm{T}$ he most of chronic inflammatory diseases are accompanied by a decrease in the availability of oxygen to the tissues. In the process of evolution, tissue cells have adapted to changing environmental conditions and significant fluctuations in oxygen levels, trying to maintain internal homeostasis. As a result, an oxygen-sensory system was formed, a highly sensitive regulator that controls the expression of more than 300 genes in the human body [1-3].

Special attention of scientists was focused on studying the role of the oxygen-sensory system in the cellular response to hypoxia, its coordinated work in the processes of adaptation, survival and differentiation under conditions of changing oxygen content. In this case, the so-called hypoxia-inducible transcription factors (HIFs) are mediators. Expression of HIFs occurs in almost all cells of the body $[4,5,12]$. This is realized in various compensatory reactions: gene expression, activation of erythropoiesis and angiogenesis, a decrease in apoptosis, an increase in glucose utilization in cells due to the regulation of the expression of glycolytic enzymes and glucose transporters, regulation of the cell cycle, expression of insulin-like growth factor-2, endothelin-1, etc. As a result, HIFs act as key mechanisms of the pathogenesis of inflammatory diseases of organs and systems: reflux esophagitis $[25,26]$ and colitis
[23, 24], rheumatoid arthritis [30, 31], pyelonephritis, glomerulonephritis, and renal failure [42, 43], anemias of various origins [44], as well as osteosarcoma [35], metabolic disorders [38-40] and myocardial ischemia [55-57].

The importance of the discovery of hypoxia-inducible factors for clinical medicine, understanding the pathogenesis and changing the treatment strategy of many diseases is confirmed by the award of the Nobel Prize to 2019 laureates in physiology and medicine William G. Kaelin Jr., Sir Peter J. Ratcliffe and Gregg L. Semenza, who described them [6].

Today, the transcription factors of HIFs are presented as a collection of heterodimeric proteins, each of which contains two subunits: HIF-a and HIF- $\beta$ known as the "aryl hydrocarbon receptor nuclear translocator" (ARNT). The HIF- $\beta$ subunit, an oxygen-unregulated protein, is expressed constitutively and continuously. The HIF-a subunit is sensitive to fluctuations in oxygen $[2,7]$. Three isoforms of HIF-a are known: HIF-1a, HIF-2a, HIF-3a. The regulation of the a subunit under normoxia is carried out in several ways. The most significant is the path of degradation [10]. Under aerobic conditions, HIF-a undergoes proteasomal degradation, the catalytic enzymes of which are prolyl hydroxylases (PHDs), hydroxylating proline amino acid residues (Pro402, Pro564, Pro405, Pro531) within the oxy-

(C) 2021 Shevchenko N. S. et al. This is an open-access article distributed under the terms of the Creative Commons Attribution License, which permits unrestricted use, distribution, and reproduction in any medium, provided the original author and source are credited. 
gen-dependent degradation domain (ODD) of HIF. Three PHDs proteins have been identified: PHD1, 2 and 3. Hydroxylated HIF binds to the von HippelLindau protein (PVHL), which directs it to further degradation by the proteasome. The tumor suppressor PVHL is necessary for the recognition of ubiquitin ligase and ubiquitination the HIF-a subunit. The VHL-HIF- $1 \alpha$ interaction requires an activity that is simultaneously dependent on oxygen and iron levels $[8,9]$. Another degradation pathway is provided by the oxygen-dependent enzyme FIH-1 (factor inhibiting HIF-1) by hydroxylating asparagine residues from the c-terminal region of HIF. This mechanism also leads to degradation of the a subunit $[1,2,11]$.

However, under hypoxic conditions or in the absence of the cofactors Fe (II) and 2-oxoglutarate, PHDs are inactivated during degradation, which prevents PVHL binding. Under these conditions, HIFs- $\alpha$ are stabilized, accumulate, moving into the cell nucleus, combine with HIF- $\beta$ into heterodimers at the target gene loci, and regulate the expression of the so-called HIF-dependent genes [2, 5, 12]. The group of HIF-dependent genes includes the erythropoietin gene, stem cell factor, antiapoptotic factors, main glycolysis enzymes, vascular endothelial growth factor (VEGF), interleukin-8, etc. [12, 21]. In addition to the hypoxic pathway of regulation of HIFs, the literature contains data on non-hypoxic pathways. Factors such as reactive oxygen species (ROS), tumor necrosis factor (TNFa), interleukin-1 (IL-1) and interleukin-18 (IL-18), angiotensin, bacterial polysaccharides can also activate the expression of HIFs [11].

Especially in pathological conditions, such as a tumor process, with an increasing demand for oxygen and hypoxia of growing tissues, new levels of gene expression are programmed. Studies on various cultures of cancer cells have shown a noticeable decrease in the expression of HIF-1 mRNA and VHL tumor suppressor mRNA with induction of the HIF-1 mRNA protein, however, the severity of the changes has a cell-specific character. In the course of experiments, it was revealed that oxygen deficiency in tissues is not the only regulatory mechanism of HIF-1 mRNA expression. A decrease in the content of iron ions, which activate the action of prolyl hydroxylases, also significantly decreases the expression of HIF-1 mRNA, which is consistent with the above information on the role of iron ions in the pathways of HIFs degradation [12].

It is also necessary to mention the importance of HIFs in ensuring the stability of cellular mitosis of both healthy cells and their role in the emerging imbalance and oncogenesis and metastasis. We consider important information on the relationship between HIF and the implementation of the Warburg effect, which, under conditions of oxygen deficiency and tumor growth, demonstrates the selection of the glycolytic metabolic pathway to ensure the conservation of metabolic energy for the degenerated cells with the final reaction product, lactate $[14,15]$. It is believed that the same mechanism affects the transformation of immune cells. An alteration in the phenotypic properties of macrophages M1 towards M2 with anti-inflammatory properties and an increase in the production of cytokines, transforming growth factor beta (TGF- $\beta 1$ ), interleukin-10 and VEGF have been described. A similar mechanism is possible with the initiation of immune-inflammatory reactions upon HIF activation [19]. In this regard, the fact of activation of intracellular nuclear factor kappa B (NF-kB), which suppresses apoptosis, is important, as well as the fact of the effect of NF-kB on the activation of the HIF pathway under hypoxic conditions [11, 20].

Accelerated tumor growth occurs against the background of glycolysis activation and inhibition of mitochondrial function. As shown in some studies, changes in tissue oxygen consumption can significantly affect the above processes. Regulation is mediated by HIF-1, which is required to reduce oxygen consumption by mitochondria during hypoxia. HIF-1 $\alpha$ induces glycolytic enzymes, in particular pyruvate dehydrogenase kinase 1 (PDK1) and via fructose-2,6-bisphosphate activator (F-2,6-P2), and at the same time suppresses mitochondrial activity, and therefore tissue oxygen demand [13-15]. F-2,6-P2 levels in cells are retained by the enzyme the 6-phosphofructo-2-kinase/fructose-2,6-bisphosphatase (PFKFB). Recent studies have shown a strong association with hypoxia and the effect of the HIF-1alpha protein on the expression of the PFKFB-3 and PFKFB-4 gene in cancer cells as well as VEGF. It was noted that the severity of PFKFB expression positively correlates with the degree of malignancy in different lines of cancer cells and with the level of VEGF expression [16-18].

Thus, HIFs are involved in various physiological and pathological processes, ranging from the maintenance of internal homeostasis, carbohydrate metabolism, energy metabolism, regenerative and adaptive processes, tissue remodeling, erythropoiesis, etc. to active participation in the development of many diseases. 
The purpose of this review was to summarize current knowledge about the role of hypoxic signaling in the pathogenesis of various diseases that are most relevant to the pediatric population, such as diseases of the gastrointestinal tract, osteoarticular system, kidneys, hematological, endocrine and metabolic disorders; coverage of the latest achievements in this area, determination of the practical significance of research.

The analysis included 40 publications, which present the studies of scientists from the USA, China, Korea, France, Ukraine and Russia, where the activation or inhibition of HIFs and their influence on the development of the above pathological conditions were studied. The results of the studies considered were carried out both ex vivo, on cell culture and slide mount, and in vivo, in animals (transgenic mice) and humans. The subjects of the study were biopsy material, tissue sections, tissue cell lysates, plasma or blood serum. Determination of HIFs in most of the works was carried out using enzyme-linked immunosorbent assay (ELISA).

Among the publications presented, about 15\% are devoted to changing the view on the pathogenesis of individual inflammatory diseases of the gastrointestinal tract. Thus, a study conducted on animal models at the Department of Gastroenterology, Molecular Physiology of the University of Michigan, USA, showed a relationship between excessive activation of HIF-2 in the intestinal epithelium and the development of a powerful inflammatory reaction in the form of colitis, which is accompanied by an increase in the expression of pro-inflammatory mediators, an increase in colon carcinogenesis, and decreased survival among younger populations of mice [23, 24]. In the publications of the group of authors (Huo X et al. and Rhonda F. Souza et al, Dallas, Texas, USA), the concept that reflux esophagitis is the result of acid burn was refuted. These studies explored the alternative hypothesis that this pathology is the result of reflux-stimulated production of pro-inflammatory molecules mediated by hypoxiainducible factors (HIFs) [25, 28]. In the cells of the squamous epithelium of the esophagus exposed to bile salts, the activation of HIFs, an increase in intracellular reactive oxygen species, which reduced the function of prolyl hydroxylase and stabilized HIF- $2 \alpha$, were proved. This was the reason for the expression of proinflammatory molecules: interleukin-8, tumor necrosis factor, etc. Thus, it is possible to consider reflux esophagitis as a HIF-associated disease. In addition, a relationship has been established between high levels of ROS and HIFs with the development of Barrett's metaplasia and carcinoma $[26,27]$.

The mechanisms of the relationship between HIFs activity and the development of diseases of the musculoskeletal system are discussed in detail in $20 \%$ of scientific publications. Hypoxic inflammation accompanies the development of arthritis, primarily bone remodeling, an increase in their subchondral density, changes in the parameters of bone vascularization, which lead to ischemia. Studies have shown that tissue hypoxia can influence the development of the inflammatory process through overexpression of HIFs, which in turn induce leptin production by fibroblasts in synergism with vitamin $D_{3}$ [29]. The pathogenetic relationship between HIFs and a systemic disease such as rheumatoid arthritis is supported by another study by a group of scientists from the Republic of Korea. The work noted the expression of HIF-2 $\alpha$ mainly in fibroblast-like synoviocytes (FLS), stimulation of their proliferation and expression of various catabolic factors [33]. In addition, HIF-2 $\alpha$-dependent regulation of interleukin-6 in FLS stimulates the differentiation of TH17 cells - the most important effectors of the pathogenesis of rheumatoid arthritis [30]. This concept is supported by other authors, indicating the role of hypoxia in the activation of proliferation and survival of endothelial cells and fibroblast-like synoviocytes. The result is an increase in synovial angiogenesis through the expression of hypoxia-induced molecules, including vascular endothelial growth factor, decreased mitochondrial respiration, excessive production of reactive oxygen species, loss of adenosine triphosphate (ATP), increased oxidative damage, and dysfunction of immune cells [31, 32].

Other studies have shown (Srinivas V. et al., 2009; Maes, C. et al., 2012) that the oxygen-sensory system affects the process of endochondral ossification. Data are presented in which conditional ablation of HIF-1 in chondrocytes of the growth plate leads to disruption of skeletal development associated with massive cell death in the inner layer of chondrocytes of the growth plate. This confirms the important role of HIFs in the regulation of the development of the human skeleton, the formation of bone and cartilage tissue and their regeneration. HIF-s is also a potent regulator of autophagy and apoptosis of chondrocytes [4, 34]. Human osteosarcoma specimens have been studied as the most 
common primary malignant neoplasm of bone tissue [35]. There was a correlation between HIF-1 overexpression and tumor metastasis, poor patient survival. The above data confirm the significant role of oxygen signaling pathways in the development of chronic inflammatory and oncological diseases of the joints and bones.

The involvement of HIFs in the regulation of metabolic processes is also confirmed by studies carried out in France (University Paris-Descartes) and Japan on transgenic mice. Conclusions were drawn about the key role of HIFs in iron metabolism by regulating the expression of iron-binding proteins: ferroportin, divalent metal transporter (DMT1), duodenal cytochrome $B$ reductase, hepcidin, etc. Specific deletion of HIF-2 $\alpha$ led to a decrease in hepcidin expression and iron levels in the blood, liver. Taken together, these results suggest that HIFs are required in the regulation of iron metabolism (8\% of the reports analyzed). Hypoxia induces HIF-1 $\alpha$ and, accordingly, erythropoiesis. It has been noted that monitoring HIFs levels and their inhibition could potentially be used in patients with iron metabolic disorders. [22, 36, 37].

According to studies that studied the pathogenetic role of hypoxia-induced factors in the development of pathological conditions associated with endocrine diseases (11\% of the analyzed reports), it was reported about the relationship between the activation of HIF-induced processes in adipocytes in obesity. In the early stages of adipose tissue dysfunction, stabilization of HIF-1 $\alpha$ is noted, leading to further inflammation and a decrease in insulin sensitivity [54]. Subsequently, activation of HIF-2 $\alpha$ initiates chronic inflammation and fibrosis of adipose tissue by increasing the level of secreted inflammatory cytokines such as IL-1, IL-6, TNF- $\alpha$, and transforming growth factor- $\beta$ and the development of hypertrophic cardiomyopathy [39, 40]. Disruption of adipogenesis in white adipose tissue has been associated with increased levels of HIF-2 $\alpha$. Studies in mice have shown an increase in the processes of angiogenesis in the heart, the number of cardiomyocytes, the development of fibrosis and impaired functional state of the heart muscle against the background of HIF$2 \alpha$ activation in adipocytes [38]. In one of the recent studies of thyroid-associated orbitopathy on a threedimensional culture of human orbital fibroblasts, Hikage F. et al. demonstrated the role of overexpression of HIFs in the stimulation of the lysyl oxidase (LOX) "cross-linking" enzyme and subsequent accelera- tion of periorbital fibrous tissue remodeling. These results indicate a molecular mechanism underlying the process of thyroid-associated orbitopathy [41].

Among all the studies presented, only three focused on information on pathology in children. Two publications reported that patients aged 1 to 17 years with various forms of chronic pyelonephritis had high plasma levels of HIF-1a in comparison with the control group. Conclusions were drawn about the relationship of chronic kidney disease with HIF activation and the possibility of using it as a predictor of an unfavorable course of the disease and a marker for the effectiveness of therapy. In a more recent study, HIF-1a was determined among a cohort of patients aged 5 to 18 years with glomerulonephritis and varying degrees of renal failure. The results showed a significant increase in the level of HIF-1a in blood plasma in comparison not only with the control group, but also depending on the severity of renal failure [42, 43]. Another pilot study of the determination of hypoxia-induced factor was carried out in children from 10 months to 3.5 years old and with iron deficiency anemia. A 2.5-fold increase in serum HIF-1a level before the start of therapy compared with healthy peers was associated with hypoxia against the background of anemia. After treatment, the HIF-la level returned to normal, which also confirms the importance of the signaling system in oxygen homeostasis and the possibility of using HIF to control the effectiveness of therapy [44].

To date, there is already a sufficient number of works and clinical studies in which the expediency of using specific inhibitors of HIF-prolyl hydroxylases for the treatment of oncopathology [47, 48], HIF stabilizers for the treatment of anemia associated with renal pathology [45], and cardiometabolic diseases are discussed [46, 53]. Researchers have identified a number of therapeutic effects of HIFs stabilizers that still require further study, but can be used to treat ischaemic heart disease and cardiomyopathy [49].

The data on the drug roxadustat (Evrenzo), developed jointly by FibroGen and AstraZeneca and registered today by the National Agency for Medical Products of the People's Republic of China and the Ministry of Health, Labor and Welfare of Japan (MHLW). Also, along with the introduction of HIF stabilizers, clinical trials of HIF-2 inhibitors started in 2014. The Kidney Cancer Program at Harold C. Simmons Comprehensive Cancer Center at UT Southwestern Medical Center is testing PT2385, an 
oral drug for the treatment of kidney cancer, which has shown positive results in patients with advanced or metastatic renal cell carcinoma [50-52].

Conclusions. Summarizing modern concepts of the fundamental importance of hypoxia-induced factors, it is necessary to emphasize their multifaceted pathophysiological role in the development of chronic human pathology. Present in all tissues and organs, stabilizing under conditions of both systemic hypoxia and local ischemia, HIFs control the transcription of the most pathogenetically significant molecules. Despite the fact that these issues have been studied since the 90s of the last century, when hypoxia-induced factors were discovered, their role in the pathogenesis of many diseases remains unclear. The studies discussed above expand our understanding of the mechanisms of development of severe tissue damage and determine new therapeutic strategies.

Diseases such as rheumatoid arthritis, diseases of the gastrointestinal tract, blood, kidneys, metabolic disorders observed in children are often manifested by combined lesions. HIFs are directly involved in pathogenesis, creating a pathophysiological platform for triggering further molecular transformations, which makes it possible to speak of HIFs-associated comorbidity. Despite the variety of scientific works, among the child population, isolated works are devoted to this issue. It can be assumed that in the child's body, the adaptation mechanism works in an identical sequence, retaining the importance of the role of HIFs activation. New aspects of the pathogenesis of the development of chronic pathology require further study and in children can be considered as the basis for changes in treatment tactics.

Conflict of interest. Authors have completed the Unified Conflicts of Interest form at http://ukrbiochemjournal.org/wp-content/uploads/2018/12/ coi_disclosure.pdf and declare no conflict of interest.

\section{РОЛЬ ФАКТОРІВ, ЩО ІНДУКУЮТЬСЯ ГІПОКСІЄЮ, В ПАТОГЕНЕЗІ ХРОНІЧНИХ ЗАХВОРЮВАНЬ}

\author{
Н. С. Шевченко, Н. В. Крутенко \\ Т. В. Зимнииька, К. В. Волочин
}

Харківський національний університет ім. В. Н. Каразіна, кафедра педіатрії № 2, Україна;

凶e-mail: n.v.krutenko@karazin.ua

Огляд присвячено сучасному розумінню ролі індукованих гіпоксією факторів (HIFs) як регуляторів кисневозалежних реакцій та індукторів експресії низки генів в організмі людини. Основну увагу приділено результатам досліджень, які демонструють найсуттєвіші патогенетичні взаємозв'язки між активацією або гальмуванням внутрішньоклітинної системи HIF, розвитком запального процесу в різних органах, хронічними захворюваннями шлунково-кишкового тракту, кістково-суглобової системи, нирок, а також гематологічними, ендокринними та метаболічними порушеннями.

К л ю ч о в і с ло в а: HIFs, гіпоксія, обмін речовин, хронічна патологія, патогенез.

\section{References}

1. Loboda A, Jozkowicz A, Dulak J. HIF-1 and HIF-2 transcription factors - similar but not identical. Mol Cells. 2010; 29(5): 435-442.

2. Pugh CW, O'Rourke JF, Nagao M, Gleadle JM, Ratcliffe PJ. Activation of hypoxia-inducible factor-1; definition of regulatory domains within the alpha subunit. J Biol Chem. 1997; 272(17): 11205-11214.

3. Glukhanyuk E. Hypoxia, non-hypoxic hypoxia and immunity. "Biomolecule". Immunology, medicine, cytology. 2015 November. (In Russian). Available at https://biomolecula.ru/ articles/gipoksiia-negipoksicheskaia-gipoksiiai-immunitet. 
4. Maes C, Carmeliet G, Schipani E. Hypoxiadriven pathways in bone development, regeneration and disease. Nat Rev Rheumatol. 2012; 8(6): 358-366.

5. Wiesener MS, Jürgensen JS, Rosenberger C, Scholze CK, Hörstrup JH, Warnecke C, Mandriota S, Bechmann I, Frei UA, Pugh CW, Ratcliffe PJ, Bachmann S, Maxwell PH, Eckardt KU. Widespread hypoxia-inducible expression of HIF-2alpha in distinct cell populations of different organs. FASEB J. 2003; 17(2): 271-273.

6. Press release: The Nobel Prize in Physiology or Medicine 2019. NobelPrize.org. Nobel Media AB 2020. Tue. 13 Oct 2020. Available at https:// www.nobelprize.org/prizes/medicine/2019/ press-release/

7. O'Rourke JF, Dachs GU, Gleadle JM, Maxwell PH, Pugh CW, Stratford IJ, Wood SM, Ratcliffe PJ. Hypoxia response elements. Oncol Res. 1997; 9(6-7): 327-332.

8. Cockman ME, Masson N, Mole DR, Jaakkola P, Chang GW, Clifford SC, Maher ER, Pugh CW, Ratcliffe PJ, Maxwell PH. Hypoxia inducible factor-alpha binding and ubiquitylation by the von Hippel-Lindau tumor suppressor protein. $J$ Biol Chem. 2000; 275(33): 25733-25741.

9. Frise MC, Cheng HY, Nickol AH, Curtis MK, Pollard KA, Roberts DJ, Ratcliffe PJ, Dorrington KL, Robbins PA. Clinical iron deficiency disturbs normal human responses to hypoxia. J Clin Invest. 2016; 126(6): 2139-2150.

10. Stolze IP, Mole DR, Ratcliffe PJ. Regulation of HIF: prolyl hydroxylases. Novartis Found Symp. 2006; 272: 15-25; discussion 25-36.

11. Taylor CT. Interdependent roles for hypoxia inducible factor and nuclear factor-kappaB in hypoxic inflammation. J Physiol. 2008; 586(17): 4055-4059.

12. Bobarykina AYu, Minchenko DO, Opentanova IL, Kovtun OO, Komisarenko SV, Esumi H, Minchenko OH. HIF-1alpha, HIF2alpha and VHL mRNA expression in different cell lines during hypoxia. Ukr Biokhim Zhurn. 2006; 78(2): 62-72. (In Ukrainian).

13. Papandreou I, Cairns RA, Fontana L, Lim AL, Denko NC. HIF-1 mediates adaptation to hypoxia by actively downregulating mitochondrial oxygen consumption. Cell Metab. 2006; 3(3): 187-197.
14. Chen Y, Cairns R, Papandreou I, Koong A, Denko NC. Oxygen consumption can regulate the growth of tumors, a new perspective on the Warburg effect. PLoS One. 2009; 4(9): e7033.

15. Minchenko A, Leshchinsky I, Opentanova I, Sang N, Srinivas V, Armstead V, Caro J. Hypoxia-inducible factor-1-mediated expression of the 6-phosphofructo-2-kinase/fructose-2,6bisphosphatase-3 (PFKFB3) gene. Its possible role in the Warburg effect. $J$ Biol Chem. 2002; 277(8): 6183-6187.

16. Minchenko $\mathrm{OH}$, Ogura $\mathrm{T}$, Opentanova IL, Minchenko DO, Esumi H. Splice isoform of 6-phosphofructo-2-kinase/fructose-2,6-bisphosphatase-4: expression and hypoxic regulation. Mol Cell Biochem. 2005; 280(1-2): 227-234.

17. Minchenko OH, Tsuchihara K, Minchenko DO, Bikfalvi A, Esumi H. Mechanisms of regulation of PFKFB expression in pancreatic and gastric cancer cells. World J Gastroenterol. 2014; 20(38): 13705-13717.

18. Minchenko O, Opentanova I, Minchenko D, Ogura T, Esumi H. Hypoxia induces transcription of 6-phosphofructo-2-kinase/ fructose-2,6-biphosphatase-4 gene via hypoxiainducible factor-1alpha activation. FEBS Lett. 2004; 576(1-2): 14-20.

19. Lin S, Sun L, Lyu X, Ai X, Du D, Su N, Li H, Zhang L, Yu J, Yuan S. Lactate-activated macrophages induced aerobic glycolysis and epithelial-mesenchymal transition in breast cancer by regulation of CCL5-CCR5 axis: a positive metabolic feedback loop. Oncotarget. 2017; 8(66): 110426-110443.

20. Koong AC, Chen EY, Mivechi NF, Denko NC, Stambrook P, Giaccia AJ. Hypoxic activation of nuclear factor-kappa B is mediated by a Ras and Raf signaling pathway and does not involve MAP kinase (ERK1 or ERK2). Cancer Res. 1994; 54(20): 5273-5279.

21. Gleadle JM, Ratcliffe PJ. Induction of hypoxiainducible factor-1, erythropoietin, vascular endothelial growth factor, and glucose transporter-1 by hypoxia: evidence against a regulatory role for Src kinase. Blood. 1997; 89(2): 503-509.

22. Xu MM, Wang J, Xie JX. Regulation of iron metabolism by hypoxia-inducible factors. Sheng Li Xиe Bao. 2017; 69(5): 598-610. 
23. Solanki S, Devenport SN, Ramakrishnan SK, Shah YM. Temporal induction of intestinal epithelial hypoxia-inducible factor- $2 \alpha$ is sufficient to drive colitis. Am J Physiol Gastrointest Liver Physiol. 2019; 317(2): G98-G107.

24. Van Welden S, Selfridge AC, Hindryckx P. Intestinal hypoxia and hypoxia-induced signalling as therapeutic targets for IBD. Nat Rev Gastroenterol Hepatol. 2017; 14(10): 596611.

25. Souza RF, Bayeh L, Spechler SJ, Tambar UK, Bruick RK. A new paradigm for GERD pathogenesis. Not acid injury, but cytokinemediated inflammation driven by HIF- $2 \alpha$ : a potential role for targeting HIF-2 $\alpha$ to prevent and treat reflux esophagitis. Curr Opin Pharmacol. 2017; 37: 93-99.

26. Huo X, Agoston AT, Dunbar KB, Cipher DJ, Zhang X, Yu C, Cheng E, Zhang Q, Pham TH, Tambar UK, Bruick RK, Wang DH, Odze RD, Spechler SJ, Souza RF. Hypoxia-inducible factor- $2 \alpha$ plays a role in mediating oesophagitis in GORD. Gut. 2017; 66(9): 1542-1554.

27. Feagins LA, Zhang HY, Zhang $X$, HormiCarver K, Thomas T, Terada LS, Spechler SJ, Souza RF. Mechanisms of oxidant production in esophageal squamous cell and Barrett's cell lines. Am J Physiol Gastrointest Liver Physiol. 2008; 294(2): G411-G417.

28. Souza RF, Huo X, Mittal V, Schuler CM, Carmack SW, Zhang HY, Zhang X, Yu C, Hormi-Carver K, Genta RM, Spechler SJ. Gastroesophageal reflux might cause esophagitis through a cytokine-mediated mechanism rather than caustic acid injury. Gastroenterology. 2009; 137(5): 1776-1784.

29. Bouvard B, Abed E, Yéléhé-Okouma $M$, Bianchi A, Mainard D, Netter P, Jouzeau JY, Lajeunesse D, Reboul P. Hypoxia and vitamin D differently contribute to leptin and dickkopfrelated protein 2 production in human osteoarthritic subchondral bone osteoblasts. Arthritis Res Ther. 2014; 16(5): 459.

30. Ryu JH, Chae CS, Kwak JS, Oh H, Shin Y, Huh YH, Lee CG, Park YW, Chun CH, Kim YM, Im SH, Chun JS. Hypoxia-inducible factor- $2 \alpha$ is an essential catabolic regulator of inflammatory rheumatoid arthritis. PLoS Biol. 2014; 12(6): e1001881.
31. Fearon U, Canavan M, Biniecka M, Veale DJ. Hypoxia, mitochondrial dysfunction and synovial invasiveness in rheumatoid arthritis. Nat Rev Rheumatol. 2016; 12(7): 385-397.

32. Konisti S, Kiriakidis S, Paleolog EM. Hypoxia a key regulator of angiogenesis and inflammation in rheumatoid arthritis. Nat Rev Rheumatol. 2012; 8(3): 153-162.

33. Huh YH, Lee G, Song WH, Koh JT, Ryu JH. Crosstalk between FLS and chondrocytes is regulated by HIF-2 $\alpha$-mediated cytokines in arthritis. Exp Mol Med. 2015; 47(12): e197.

34. Srinivas V, Bohensky J, Zahm AM, Shapiro IM. Autophagy in mineralizing tissues: microenvironmental perspectives. Cell Cycle. 2009; 8(3): 391-393.

35. Rankin EB, Giaccia AJ, Schipani E. A central role for hypoxic signaling in cartilage, bone, and hematopoiesis. Curr Osteoporos Rep. 2011; 9(2): 46-52.

36. Mastrogiannaki M, Matak P, Keith B, Simon MC, Vaulont S, Peyssonnaux C. HIF-2alpha, but not HIF-1alpha, promotes iron absorption in mice. $J$ Clin Invest. 2009; 119(5): 1159-1166.

37. Peyssonnaux C, Zinkernagel AS, Schuepbach RA, Rankin E, Vaulont S, Haase VH, Nizet V, Johnson RS. Regulation of iron homeostasis by the hypoxia-inducible transcription factors (HIFs). J Clin Invest. 2007; 117(7): 1926-1932.

38. Lin Q, Yun Z. The Hypoxia-Inducible Factor Pathway in Adipocytes: The Role of HIF-2 in Adipose Inflammation and Hypertrophic Cardiomyopathy. Front Endocrinol (Lausanne). 2015; 6: 39.

39. Lin Q, Huang Y, Booth CJ, Haase VH, Johnson RS, Simon, Giordano FJ, Yun Z. Activation of hypoxia-inducible factor-2 in adipocytes results in pathological cardiac hypertrophy. $J$ Am Heart Assoc. 2013; 2(6): e000548.

40. Giaccia AJ. HIF-2: the missing link between obesity and cardiomyopathy. J Am Heart Assoc. 2013; 2(6): e000710.

41. Hikage F, Atkins S, Kahana A, Smith TJ, Chun TH. HIF2A-LOX Pathway Promotes Fibrotic Tissue Remodeling in ThyroidAssociated Orbitopathy. Endocrinology. 2019; 160(1): 20-35.

42. Maydannik VG, Burlaka EA, Bagdasarova IV, Lavrenchuk OV. Cellular hypoxia as a 
mechanism of renal disorders during the chronic pyelonephritis in children. Modern Pediatr. 2013; 3(51): 132-135. (In Ukrainian).

43. Maidannyk VG, Burlaka EA, Bagdasarova IV, Fomina SP, Neponyaschiy VM. Role of hypoxiainduced apoptosis in chronic glomerulonephritis progression in children. Ukr Zhurn Nephrol Dial. 2014; (4(44)): 41-45. (In Ukrainian).

44. Levina AA, Makeshova AB, Mamukova YuI, Romanova EA, Sergeeva AI, Kazyukova TV. Regulation of oxygen homeostasis. Hypoxiainducible factor (HIF) and its significance in oxygen homeostasis. Pediatriya. 2009; 87(4): 92-97. (In Russian).

45. Maxwell PH. A new approach to treating renal anaemia. Nat Rev Nephrol. 2019;15(12):731-732.

46. Aitbaev KA, Murkamilov IT, Fomin VV. Inhibition of HIF-prolyl 4-hydroxylases as a promising approach to the therapy of cardiometabolic diseases. Ter Arkh. 2018; 90(8): 86-94. (In Russian).

47. Semenza GL. Targeting HIF-1 for cancer therapy. Nat Rev Cancer. 2003;3(10):721-732.

48. Yeh,TL, Leissing TM, Abboud MI, Thinnes CC, Atasoylu O, Holt-Martyn JP, Zhang D, Tumber A, Lippl K, Lohans CT, Leung I, Morcrette H, Clifton IJ, Claridge T, Kawamura A, Flashman E, $\mathrm{Lu} \mathrm{X,} \mathrm{Ratcliffe} \mathrm{PJ,} \mathrm{Chowdhury} \mathrm{R,} \mathrm{Pugh} \mathrm{CW,}$ Schofield CJ. Molecular and cellular mechanisms of HIF prolyl hydroxylase inhibitors in clinical trials. Chem Sci. 2017; 8(11): 7651-7668.

49. Bishop T, Ratcliffe PJ. HIF hydroxylase pathways in cardiovascular physiology and medicine. Circ Res. 2015; 117(1): 65-79.

50. Cho H, Du X, Rizzi JP, Liberzon E, Chakraborty AA, Gao W, Carvo I, Signoretti S, Bruick RK, Josey JA, Wallace EM, Kaelin WG. On-target efficacy of a HIF- $\alpha$ antagonist in preclinical kidney cancer models. Nature. 2016; 539(7627): 107-111.
51. New HIF-2 kidney cancer therapy more effective than current treatment, study shows. UT Southwestern Medical Center public release. 2016 Sep 5. Regime of access : https://www. eurekalert.org/pub_releases/2016-09/usmcnhk090216.php.

52. Chen W, Hill H, Christie A, Kim MS, Holloman E, Pavia-Jimenez A, Homayoun F, Ma Y, Patel N, Yell P, Hao G, Yousuf Q, Joyce A, Pedrosa I, Geiger $\mathrm{H}$, Zhang $\mathrm{H}$, Chang J, Gardner $\mathrm{KH}$, Bruick RK, Reeves C, Hwang TH, Courtney K, Frenkel E, Sun X, Zojwalla N, Wong T, Rizzi JP, Wallace EM, Josey JA, Xie Y, Xie XJ, Kapur P, McKay RM, Brugarolas J. Targeting renal cell carcinoma with a HIF-2 antagonist. Nature. 2016; 539(7627): 112-117.

53. Eltzschig HK, Bratton DL, Colgan SP. Targeting hypoxia signalling for the treatment of ischaemic and inflammatory diseases. Nat Rev Drug Discov. 2014; 13(11): 852-869.

54. Halberg N, Khan T, Trujillo ME, WernstedtAsterholm I, Attie AD, Sherwani S, Wang ZV, Landskroner-Eiger S, Dineen S, Magalang UJ, Brekken RA, Scherer PE. Hypoxia-inducible factor 1alpha induces fibrosis and insulin resistance in white adipose tissue. Mol Cell Biol. 2009; 29(16): 4467-4483.

55. Semenza GL. Oxygen sensing, hypoxia-inducible factors, and disease pathophysiology. Аnnu Rev Pathol. 2014; 9: 47-71.

56. Semenza GL. Hypoxia-inducible factor 1 and cardiovascular disease. Annu Rev Physiol. 2014; 76: 39-56.

57. Doaa Fouad, Naglaa Idriss, Sherif Sayed. Plasma Levels of Soluble Receptors of Advanced Glycation End Products Angiogenin and Hypoxia Inducible Factor-1 Alpha in Acute Coronary Syndrome. Heart Mirror J. 2013; 7(1): 52-59. 